\title{
Assessing the Value of Agroecosystem Services in Warmia and Mazury Province Using Choice Experiments
}

\author{
Stanisław Bielski $^{1}{ }^{(\mathbb{D}}$, Renata Marks-Bielska ${ }^{2} \mathbb{D}$, Anastasija Novikova $^{3, *}$ and Bernardas Vaznonis $^{3}$ \\ 1 Department of Agrotechnology, Agricultural Production Management and Agribusiness, \\ Faculty of Environmental Development and Agriculture, University of Warmia and Mazury in Olsztyn, \\ 10-719 Olsztyn, Poland; stanislaw.bielski@uwm.edu.pl \\ 2 Department of Economic Policy, Faculty of Economic Science, University of Warmia and Mazury in Olsztyn, \\ Oczapowskiego 4, 10-719 Olsztyn, Poland; renatam@uwm.edu.pl \\ 3 Vytautas Magnus University, K. Donelaičio str. 58, 44248 Kaunas, Lithuania; bernardas.vaznonis@vdu.lt \\ * Correspondence: anastasija.novikova@vdu.lt; Tel.: +370-6726-1959
}

Citation: Bielski, S.; Marks-Bielska, R.; Novikova, A.; Vaznonis, B. Assessing the Value of Agroecosystem Services in Warmia and Mazury Province Using Choice Experiments. Agriculture 2021, 11, 4. https://dx.doi.org/10.3390/ agriculture11010004

Received: 2 November 2020 Accepted: 19 December 2020 Published: 23 December 2020

Publisher's Note: MDPI stays neutral with regard to jurisdictional claims in published maps and institutional affiliations.

Copyright: () 2020 by the authors. Licensee MDPI, Basel, Switzerland. This article is an open access article distributed under the terms and conditions of the Creative Commons Attribution (CC BY) license (https: / / creativecommons.org/ licenses/by/4.0/).

\begin{abstract}
Due to the often-intangible benefits of agroecosystem services (AES), their cultural, social, and economic value is very difficult to quantify and integrate into decision-making and policymaking processes. The aim of this study is to assess the non-market values of AES in an exceptionally environmentally rich area of the Warmia and Mazury region (Poland), identifying consumers' preferences for them using the choice experiment (CE) method. Four AES attributes were selected for the research: (i) water quality; (ii) wildlife populations; and (iii) agricultural landscape. The study has revealed that the residents of Warmia and Mazury region were concerned about environmental issues that may be caused by agriculture. There was a demand for the provision of AES. The application of multinomial logit (MNL) model has revealed that marginal willingness to pay (MWTP) values were the highest for water quality (EUR 1.94), followed by wildlife population (EUR 1.02) and agricultural landscape (EUR 0.85). The findings have provided quantitative information related to the demand for improvements in AES through agri-environmental protection programs.
\end{abstract}

Keywords: agroecosystem services; choice experiments; preferences; willingness to pay

\section{Introduction}

Historically, agricultural systems have been primarily created for the production of food and fiber raw materials [1]. Nevertheless, they have a significant impact on the formation of cultural ecosystems and provision of different ecosystem services (ES) in rural areas: healthy and safe food, quality of surface water, air and soil, rich landscape, and biodiversity [2]. Agriculture is a managed or transformed or cultured ecosystem. Most food and other biological products are produced from agriculture as well as forestry, fishing, hunting, and harvesting activities [3]. Here, production is the use of man-made ecosystems and the use of natural ecosystem elements. In this context, according to Christiansen (1979) [3], agricultural systems are referred to as the agroecosystem, and the outputs delivered by them are referred to as the AES. The agroecosystem is the only ecosystem directly managed by people in order to meet own needs [4].

Therefore, farmers remain the key agroecosystem managers globally, and are responsible for the provision of multiple AES, in particular, food provisioning services. Besides the intensification of food production, it is very important to include farmers in the development of land management strategies [1]. On the other hand, farmers do not always have economic incentives to provide AES. When farmers receive income from the products sold, they receive no compensation for AES, so provision of AES may not be a part of their decision-making process.

Agriculture is an integral part of an agroecosystem; therefore, it is particularly important to analyze the functions of agroecosystems, reveal the concept of agroecosystem services, their social and economic benefits, and the need for special conditions for their provision. 
The AES can be classified into four groups by their public benefit: (i) provisioning services (production of food, fuel, fiber); (ii) regulating services (climate and water quality regulation, flood and disease control, waste decomposition); (iii) supporting services (processes necessary for, e.g., soil formation, nutrient cycling, and photosynthesis); (iv) cultural services (recreational, aesthetic, spiritual, agricultural landscapes, etc.) [5].

AES in comparison to ES depend not only on the biophysical processes that regulate ecosystem function, but also on the way that humans manage the ecosystem [1]. It should be noted that there is usually a contradiction between the provisioning services and provision of all other AES. Increases in food, fiber, and other trade goods often leads to a critical decline in other ES. Negative impacts of intensive agriculture occur through wildlife and landscape losses, and the degradation of soil and water quality. These negative side effects are usually referred to as agroecosystem disservices. Therefore, provision of AES mostly depends on the farming systems used. It is beneficial when there is synergy between yields and ES in the farming system. Nevertheless, in many cases, farmers have no financial incentives to provide AES, especially those that are not related to increases in farm productivity (e.g., related to climate change mitigation). Most of the AES have no market price, and farmers have little or no incentives to produce them regardless of their high societal demand [6]. Farmers are motivated to provide provisioning AES, because these services are directly related to farmers' livelihoods and income sources. However, this cannot be said for many other AES. On the contrary, their provision increases the cost of farming or leads to a loss of income. Maximization of the provisioning AES may lead to a decline in other ES and degradation of the ecosystem as a whole [1]. This is exactly what certain scientists [6] emphasize, namely, that AES are often concurrent and there are usually trade-offs between food production and provision of non-market AES.

Certain researchers [2] have noted that the level of ES could stimulate some economic activities. This is one of the reasons why cultural ES have the potential to increase public support for environmental policy. Another reason for public support for environmental policy is that ES enable people to enjoy recreation and tourism.

Developing effective agri-environmental policy schemes should take into account the attitudes of members of society about the role of agriculture providing ES. It is also very important to identify the most demanded ES that should guide policy targets, and pay famers for the delivery of these [6]. Following assessment of consumers' preferences towards provision of AES, it would be possible to develop policy measures based on economic incentives to encourage farmers to create AES. The links between agricultural policy and farmers' decisions to create AES are shown in Figure 1. 


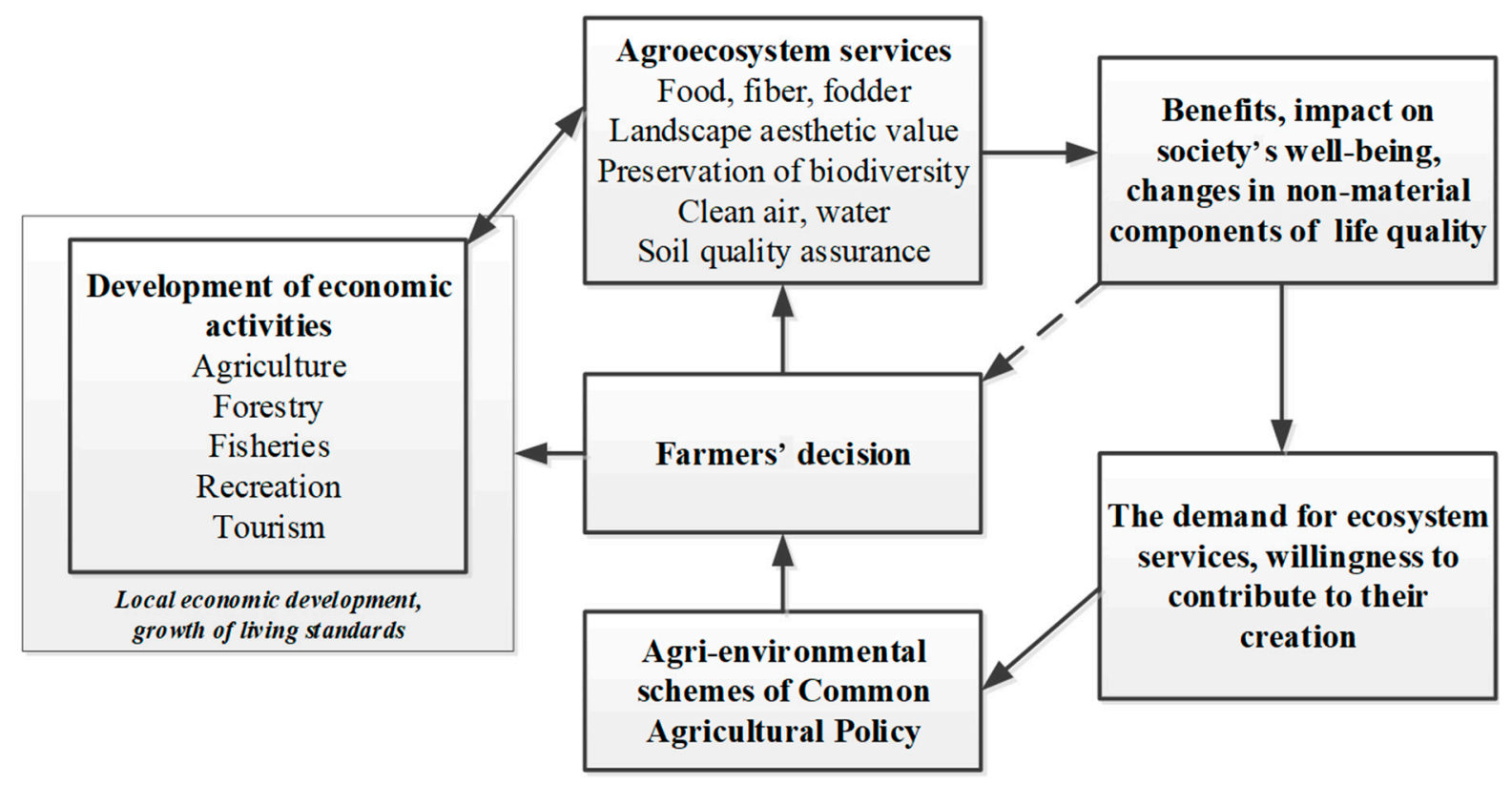

Figure 1. Links between agricultural policy and farmers' decisions to create agroecosystem services (AES).

The EU's Common Agricultural Policy has specific economic initiatives in order to ensure the provision of ecosystem services. It is focused on restoring, preserving, and enhancing ecosystems related to agriculture. The main measures are "Agri-Environment and Climate" measures, organic farming, payments to farmers in areas with handicaps (except for mountainous areas), greening and other environmental measures.

These agri-environmental programs are implemented by the means of monetary support from EU citizens who are also the consumers of such services. However, these measures are not always based on consumer expectations regarding agricultural activities and the AES they create. The analysis of consumer opinion and preferences towards AES creation and use should be included into the decision-making process of distribution of the agri-environmental payments. Literature $[7,8]$ has suggested that the stated preference methods, in particular, choice experiments (CEs) are the best techniques of evaluation of the AES or agricultural public goods when analyzing both the overall product and each component or attribute.

Several researchers have analyzed consumer preferences for AES or multiple/several agricultural public goods in the EU countries [6,9-11], focusing on particular elements or service, such as recreation [12] or agricultural landscape [13]. A few research studies were conducted in Poland, for example, Włodarczyk-Marciniak et al. (2020) implemented socio-cultural valuation of Polish agricultural landscape components by farmers [14], and Czyżewski (2020) valuated public goods from agricultural landscape [15]. However, no research was conducted about consumer preferences for AES in Poland or Polish regions. In this context, the aim of this study was to assess the non-market values of agroecosystem services in an exceptionally environmentally rich area of the Warmia and Mazury region (Poland), identifying consumers' preferences for them using the CE method. The paper is structured as follows: Section 2 describes the main characteristics of agriculture in Warmia and Mazury region; Section 3 explains the methodology applied in the research; the results of the empirical application are discussed in Section 4; and Section 5 ends the paper by presenting its main conclusions.

\section{Materials and Methods}

\subsection{Case Study: Warmia and Mazury}

Warmia and Mazury province is located in the northeast part of Poland (Figure 2) [16]. This area is one of the most attractive tourist, sightseeing, and recreational regions in Poland. 
Its population is almost 1.5 million. The capital of the region is Olsztyn. The Warmia and Mazury province is the fourth largest voivodeship in Poland (area over $24,000 \mathrm{~km}^{2}$ ).

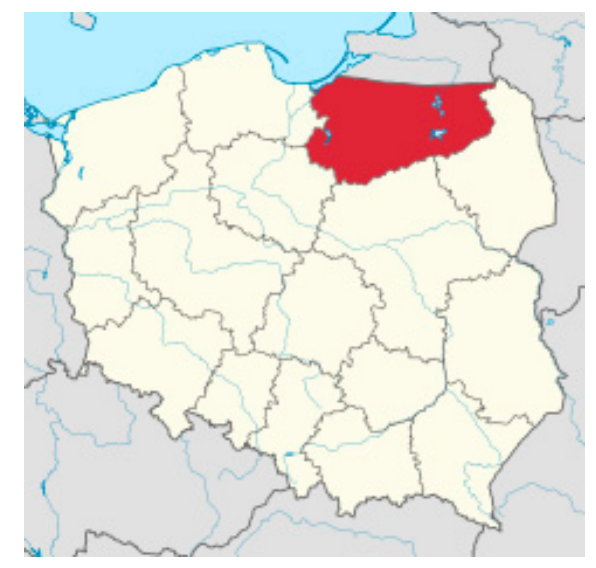

Figure 2. Study area.

Warmia and Mazury province is characterized by specific natural, economic, and social features. The most important of them include:

- A relatively low population density per unit area (more than twice lower than the average in Poland);

- Low pollution of the atmosphere of harmful emissions of gases and dust;

- Lack of soil contamination with heavy metals and lack of potential premises for the occurrence of such threats on a larger scale;

- Branched network of rivers and lakes, which causes a system of circulation of surface and deep ground water, requiring special protection, as opposed to elsewhere than in the country;

- Unique and extremely beautiful landscape diversity, enabling the development of numerous forms of tourism, recreation, and treatment;

- Diversified terrain configuration and soil mosaicism, justifying the use of appropriate directions of land use and maintaining the appropriate level of intensification of agricultural production, which results from the need to prevent erosion processes and leaching nutrients from the soil;

- Low level of industrialization of the area, including lack of environmentally troublesome industry;

- Relatively low share of people living from non-agricultural sources;

- Favorable area structure of farms;

- $\quad$ Significant area of forests [17].

Forest areas and lakes are characteristic for the nature of the region. Half of the ten largest lakes in Poland are located in Warmia and Mazury province, including the two largest ones: Śniardwy and Mamry. Forests in this climatic and geographical zone are the most natural formation. Woodiness in the Warmia and Mazury province was $31.4 \%$ (sixth in the country with an average for Poland-29.6\%) in 2017 [17].

The leading branch of the economy of the voivodeship is agriculture. The intensity of agricultural production in Warmia and Mazury province is relatively small. Data from the Central Statistical Office show that the use of NPK fertilizers per 1 ha of arable land is at a relatively low level.

The crop structure of Warmia and Mazury province is dominated by cereals $(65.5 \%)$ with the largest share being wheat, i.e., approx. one-quarter, then rape- $7.2 \%$, green maize$6.8 \%$, legumes-2.8\%, and root corn-2.4\%. Agriculture and forestry account for almost $30 \%$ of the total water consumption (including most of the water in fishponds). The irrigated area of arable land and forest covers approximately three thousand hectares. Irrigation is implemented by means of the subsoil water. There is no sprinkling or flooding. 
The demand for water is estimated to increase; however, the risk of water shortages is not expected to increase significantly in Warmia and Mazury province.

The area of Warmia and Mazury is one of the richest areas in Poland in terms of fauna. In addition to common animals, there are a lot of rare ones, including those that are at the risk of extinction.

Warmia and Mazury province has specific environmental conditions for economic development. About one-fifth of Poland's surface under water (including seawater) falls to Warmia and Mazury, which is the most in the country. Additionally, the share of this area in the total area of the province is the highest in Warmia and Mazury (about 6\%). In a large part of the province municipalities, the share of surface waters in the area of the commune exceeds $10 \%$, and forests occupy almost $10 \%$ of all such areas in the country, which is almost one-third of the province's area and is the sixth-most in Poland. Regions with special natural values which are legally protected occupy over $10 \%$ of these types of areas in Poland [18].

In addition, it should be noted that Warmia and Mazury region is an environmentally rich area, where agriculture is multifunctional, delivering multiple ecosystem services which are highly important for society. Therefore, the understanding and analysis of the preferences of residents of Warmia and Mazury concerning agroecosystem services will be useful for the improvement of agri-environmental policy in the attempt to change performance of farmers in term of sustainability. Payments to farmers have to reflect societal demand for agroecosystem services in Warmia and Mazury region.

\subsection{Experimental Design}

Lancaster's Theory of Value [19] and the Random Utility Theory [20] (Thurstone 1927) are the main theoretical basis of choice experiments. According to Lancaster's Theory, the utility for goods and services can be decomposed into individual utilities by their characteristics or attributes [9]. The function of the attributes of alternatives relevant to a given choice problem can model the choices of consumers [21]. Random Utility Theory explains the diversity of the opinions choosing the offered combinations. It is useful for analysis of the provision of attributes (and their levels) within goods and services and the relationships between these attributes [22]. The services subject to the estimation are decomposed into different attributes, which are presented at different levels in CE, thus creating different scenarios, which could be chosen by respondents during the survey [23]. In this study, CEs enabled valuation of different ES within an agroecosystem of Warmia and Mazury. Implementation of the CE for the respondents' willingness to pay, revealed as implicit price for estimation of the agroecosystem services, consists of four main stages, i.e., selection of the attributes of AES and their levels, construction of the experimental design, questionnaire design, and data collection. These stages are presented below.

The first and one of the essential stages of CEs is the selection of attributes suitable for the research. Following Novikova (2016) [24] and the analysis of environmental issues of agriculture in Warmia and Mazury [25], the attributes were selected for the present research. Lithuania and Warmia and Mazury were identified as having a similar geographical location, environmental conditions, and issues, suggesting the assumption that the attributes could be feasible for Warmia and Mazury case study. The three selected AES attributes were substantiated by extensive review of the previous research.

- Water quality-usually referred to in literature as water quality, availability, reduction in water contamination/pollution issues [26-28].

- Wildlife populations - analysis of the aspects of biodiversity (i.e., variety of species, flora and fauna, endangered species) $[9,27,29]$.

- Agricultural landscape-analysis of the aspects of the landscape (i.e., scenic views, sense of the place, suitability for recreation) $[9,28,29]$.

Each of the attributes was set to a different level. The lowest level corresponded to the status quo (current), the second level-10\% improvement in AES, and the highest level-20\% improvement achieved in AES (i.e., the best possible performance scenario). The last monetary 
attribute was personal contribution into environmental management, which was proposed to be considered on an annual basis, for a five-year period (Table 1). The selected attributes and their levels were checked by the focus group and during the pilot survey.

Table 1. Description of the attributes and their levels in the choice set.

\begin{tabular}{ccc}
\hline Attribute & Description & Levels \\
\hline \multirow{2}{*}{ Water quality (WATER) } & $\begin{array}{c}\text { Expected \% of reduction in underground } \\
\text { water pollution due to agricultural activity }\end{array}$ & 0 \\
& & 10 \\
Wildlife populations & Expected \% of improvement by protecting & 0 \\
(WILD_L) & the diversity of wildlife & 10 \\
& & 20 \\
\hline \multirow{2}{*}{ Agricultural landscape (LANDSC) } & Expected \% of improved & 0 \\
& agricultural landscape & 10 \\
& & 20 \\
\hline Cost (PRICE) & Personal contribution (EUR per year for & 12 \\
& the next 5 years) & 23 \\
& & 35 \\
& & 46 \\
\hline
\end{tabular}

The survey was divided into the set of alternative options, consisting of two alternative options (option A and option B), representing improved situations and status quo situation. The unlabeled experimental design, representing combination of attributes, was used. Following Colombo et al. [30], definitions of the levels were presented using percentage.

D-efficient fractional factorial design excluding unrealistic cases was adapted to each of the choice questions to make the statistically efficient choice design for the main survey. Thirty-six choice sets were created with linear D-optimal using SASC software, which were then distributed into four blocks. For 1-3 bocks four cards, and for the fourth block five cards were proposed. Table 2 illustrates an example of the choice cards shown to the respondents.

Table 2. Example of a choice card from the questionnaire.

\begin{tabular}{cccc}
\hline Attributes & Status Quo (No Application) & Alternative A & Alternative B \\
\hline Water quality & No change- 0 & No change-0 & $10 \%$ reduction \\
Wildlife populations & No change- 0 & $10 \%$ improvement & $10 \%$ improvement \\
Agricultural landscape & No change- 0 & $20 \%$ improvement & No change-0 \\
Personal contribution (EUR per year for the next & EUR 0 & EUR 35 & EUR 12 \\
5 years) & $\square$ & $\square$ \\
Your choice (select only one) & $\square$ & $\square$
\end{tabular}

After the questionnaire had been developed, its feasibility was tested by the pilot survey in June-July, 2019. The results of the pilot survey showed that the selected attributes, as well as their levels and questions were understood and accepted by the respondents. The final questionnaire consisted of the following three parts: (1) questions about respondents' knowledge and attitudes on farming impacts on environment; (2) choice cards with different agri-environmental options for identification of the respondents' preferences; (3) questions related to respondent socioeconomic characteristics.

\subsection{Modeling Framework}

According to the Random Utility Theory, the person chooses the alternative, which gives the highest utility. People choose among alternatives on the basis of the utility function 
with two components: a systematic (i.e., observable) component plus a random term (non-observable by the researcher) within this theoretical framework [31]:

$$
U_{i n}=V_{i n}\left(Z_{i}, S_{n}\right)+\varepsilon_{i n}
$$

where $U_{i n}$ is the utility provided by alternative $i$ to subject $n, V_{i n}$ is the systematic component of the utility, $Z_{i}$ is the vector of attributes of alternative $i, S_{n}$ is the vector of socioeconomic characteristics of the respondent $n$, and $\varepsilon$ is the random term.

The econometric analysis is based on a multinomial logit (MNL) model. The MNL is one of the available probabilistic choice models, mostly used in CEs [9,13,31,32]. According to the MNL model, the probability that an individual $n$ will choose alternative $i\left(P_{\text {in }}\right)$ among other alternatives $j(j=1 \ldots J)$ of a set $C_{n}$ is expressed by the equation [31]:

$$
P_{i n}=\frac{\exp \left(\mu V_{i n}\right)}{\sum_{j \in C} \exp \left(\mu V_{j n}\right)}
$$

where $V_{\text {in }}$ is the systematic component of the utility provided by alternative $i$, and $\mu$ is a scale parameter which is inversely proportional to the standard deviation of the error terms and usually is assumed to be equal to one [32].

The maximum likelihood method could be used to evaluate the robustness of the econometric model [33]. The willingness to pay (WTP) is calculated by estimating the marginal rates of substitution (MRS) between attributes. The implicit price is calculated as follows:

$$
W T P=-\frac{\Delta \beta_{i}}{\beta_{b i d}}
$$

where $\Delta \beta_{i}$ is the variation in utility due to the change in the level of the attribute $i$, while $\beta_{b i d}$ is the estimation of the coefficient corresponding to the attribute, expressed in monetary terms [34].

\section{Results}

\subsection{Sampling Characteristics}

The final survey was performed in September-November 2019; 550 questionnaires were distributed. We received 353 valid questionnaires, excluding protest responses and imperfectly filled-in questionnaires. The valid questionnaires were obtained, delivering 1505 choice observations. Warmia and Mazury citizens over 18 years old comprised the target population. The random sampling technique was applied during the survey. The survey was implemented using a face-to-face method, randomly selecting the respondents at different events, courses, and public places. The descriptive statistics of the respondents' main sociodemographic characteristics are presented in Table 3. 
Table 3. Sociodemographic profile of respondents $(\mathrm{N}=353)$.

\begin{tabular}{lcc}
\hline Variables & Study Sample & General Population \\
\hline & $\%$ & $\%$ \\
\hline Gender & 36.5 & \\
Male & 63.5 & 51.1 \\
Female & & 48.9 \\
Age & 86.4 & 26.7 \\
18-39 & 9.1 & 34.4 \\
$40-65$ & 4.5 & 15.3 \\
over 65 & & \\
Area of residence & 53.5 & 60.0 \\
City & 46.5 & 40.0 \\
Village & & \\
Education & 22.4 & 18.2 \\
High school & 13.9 & 22.6 \\
Comparative, special & 63.7 & 58.0 \\
secondary & & \\
Secondary and elementary & 45.6 & 9.9 \\
Monthly Income & 36.3 & 29.0 \\
<EUR 460 & 6.5 & 36.0 \\
EUR 460-745 & 11.6 & 25.1 \\
EUR 745-1000 & & \\
> EUR 1000 & &
\end{tabular}

Source: Central Statistical Office (2019).

The largest part of our sample consisted of young people aged 18-39. This did not correspond to the actual age distribution in Warmia and Mazury. Women were slightly overrepresented; the distribution of males and females in Warmia and Mazury is almost equal. Slightly more than half of the respondents were living in urban areas, and the remaining share in rural areas, which was almost in line with the Warmia and Mazury region data available. Therefore, our sample included more people of young age, with approximately EUR 460 monthly earnings. The main cause of this situation was a very high unwillingness of older people to participate in the survey. Unfortunately, the research was not provided with any additional/external funding to pay people for participation in the survey in order to ensure the representativeness of the sample. The respondents with secondary and fundamental education comprised the largest share of the sample, and the respondents with comparative and special secondary education accounted for the smallest share in the sample, which was almost in line with the distribution of the Warmia and Mazury population. The present study was primarily a demonstration study, and the first attempt to evaluate consumer preferences for AES in Warmia and Mazury. Therefore, the present paper does not consider reaching a study sample which could meet the general population characteristic to be fundamental for its purpose. It is a demonstration study.

Table 3 shows the attitudes and awareness of the agricultural impacts on the environment among the residents of Warmia and Mazury. The majority (about 65\%) of the respondents found the impacts of farming on natural environment positive and very positive. About $30 \%$ of them stated that impacts of agriculture in Warmia and Mazury were bad. Respondents were asked about their feelings concerning the environmental aspects from agriculture in Warmia and Mazury with the focus on water quality in rivers and lakes, drinking water quality, decline in flora populations, decline in fauna populations, and formation and maintenance of landscape. More than $40 \%$ of the respondents stated that they were concerned (always or very often) about water quality in the rivers and lakes. About $80 \%$ of the respondents were very concerned (always or very often) about drinking water quality. Respondents were less concerned about loss in biodiversity and agricultural landscape issues. Respondents were asked about the awareness of positive and negatives issues from agriculture. Most of them claimed that they were aware of the issues related to farming and agriculture in Warmia and Mazury (Table 4). 
Table 4. Environmental concerns of the residents of the Warmia and Mazury region.

\begin{tabular}{|c|c|c|c|c|c|c|}
\hline \multicolumn{7}{|c|}{ How do you rate the impacts of farming on the natural environment? $(\%)$} \\
\hline Very bad & Bad & No impact & & Good & & Very good \\
\hline 0.3 & 30.9 & 4.2 & & 57.8 & & 6.8 \\
\hline \multicolumn{7}{|c|}{$\begin{array}{c}\text { How often are you concerned about the following environmental aspects in Warmia } \\
\text { and Mazury? (\%) }\end{array}$} \\
\hline \multirow{2}{*}{\multicolumn{2}{|c|}{$\begin{array}{l}\text { Attributes } \\
\text { Water quality in rivers } \\
\text { and lakes }\end{array}$}} & Always & Very often & Sometimes & Rarely & Never \\
\hline & & 12.2 & 37.7 & 35.1 & 13.3 & 1.7 \\
\hline \multirow{2}{*}{\multicolumn{2}{|c|}{$\begin{array}{c}\text { Drinking water quality } \\
\text { Decline in flora populations }\end{array}$}} & 30.3 & 47.3 & 15.3 & 6.5 & 0.6 \\
\hline & & 5.1 & 20.4 & 35.7 & 32.3 & 6.5 \\
\hline \multirow{2}{*}{\multicolumn{2}{|c|}{$\begin{array}{l}\text { Decline in fauna populations } \\
\text { Formation and maintenance } \\
\text { of landscape }\end{array}$}} & 9.6 & 31.7 & 33.7 & 22.1 & 2.8 \\
\hline & & 11.0 & 32.3 & 32.9 & 19.8 & 4.0 \\
\hline \multicolumn{7}{|c|}{ Are you aware of the following environmental issues from agriculture? (\%) } \\
\hline \multicolumn{2}{|c|}{ Elements } & \multicolumn{2}{|c|}{ Yes } & \multicolumn{3}{|c|}{ No } \\
\hline \multicolumn{2}{|c|}{ Use of mineral fertilizers } & \multicolumn{2}{|c|}{79.6} & \multicolumn{3}{|c|}{20.4} \\
\hline \multicolumn{2}{|c|}{ Use of organic fertilizers } & \multicolumn{2}{|c|}{68.6} & \multicolumn{3}{|c|}{31.4} \\
\hline Use of $p$ & & \multicolumn{2}{|c|}{90.9} & \multicolumn{3}{|c|}{9.1} \\
\hline \multicolumn{7}{|c|}{ Animal urine and faeces } \\
\hline $\begin{array}{r}\text { leaching in } \\
\text { and }\end{array}$ & $\mathrm{ms}$ & \multicolumn{2}{|c|}{78.2} & \multicolumn{3}{|c|}{21.8} \\
\hline Coastwise $\mathrm{k}$ & rips & \multicolumn{2}{|c|}{47.3} & \multicolumn{3}{|c|}{52.7} \\
\hline $\begin{array}{l}\text { Management } \\
\text { and we }\end{array}$ & dows & \multicolumn{2}{|c|}{75.4} & \multicolumn{3}{|c|}{24.6} \\
\hline $\begin{array}{r}\text { Leaving } \mathrm{s} \\
\text { the } \mathrm{W}\end{array}$ & & \multicolumn{2}{|c|}{60.6} & \multicolumn{3}{|c|}{39.4} \\
\hline $\begin{array}{l}\text { Tree buffe } \\
\text { the aral }\end{array}$ & & \multicolumn{2}{|c|}{47.6} & \multicolumn{3}{|c|}{52.4} \\
\hline
\end{tabular}

\subsection{Modeling Results}

Two MNL models were estimated using the data derived from the survey with Nlogit 6 . The first model (Model I without additional variables) was a basic specification showing the importance of the choice attributes in explaining consumer preferences of the different options of environmental protection programs. The second model (Model II or with additional variables) refers to socioeconomics and knowledge about the impact of agricultural activity on environment variables in addition to the attributes of AES in the choice set. In Model I, the utility is determined by the levels of four attributes (water quality, wildlife populations, agricultural landscape, and personal contribution) in the choice sets. Thereby, Model I provides an estimate of the effect of a change in any of the attributes on the probability that the respondent chooses one of these options. Literature suggests that additional characteristics about the respondents' reveals their preferences and explains their choices better [7]. Therefore, additional socioeconomic and knowledge characteristics were included into Model II through the interaction with the water, landscape and wildlife attributes. Five additional characteristics were found to be statistically significant. Hence, they were included into Model II:

- through the interaction with water quality: respondents' awareness about the environmental issues from agriculture and area of residence;

- through the interaction with wildlife populations and income;

- through the interaction with agricultural landscape: area of residence and gender (Table 5). 
Table 5. Socioeconomic and knowledge variables included as interactions in the multinomial logit (MNL) model.

\begin{tabular}{ll}
\hline Variable & Description \\
\hline CWAR (water_res) & Interaction of water quality and residence \\
CLR (landsc_res) & Interaction of agricultural landscape and residence \\
CLG (landsc_gen) & Interaction of agricultural landscape and gender \\
CWII (wild_inc) & Interaction of wildlife populations and income \\
CWAB (wat_env) & Interaction of water quality: respondents' awareness of the environmental \\
& issues from agriculture \\
\hline
\end{tabular}

Other socioeconomic characteristics and knowledge about the impact of agricultural activity on environment were not statistically significant. Therefore, they had no impact on respondents' choices and preferences towards the water quality, wildlife populations and agricultural landscape. The estimation results of the MNL model with and without additional variables are shown in the Table 6.

Table 6. The results obtained from MNL models.

\begin{tabular}{|c|c|c|c|c|c|c|}
\hline \multirow[t]{2}{*}{ Variables } & \multicolumn{3}{|c|}{$\begin{array}{c}\text { Model I } \\
\text { without Additional Variables }\end{array}$} & \multicolumn{3}{|c|}{$\begin{array}{c}\text { Model II } \\
\text { with Additional Variables }\end{array}$} \\
\hline & Coefficients & $\begin{array}{l}\text { Standard } \\
\text { Error }\end{array}$ & $p$-Value & Coefficients & $\begin{array}{l}\text { Standard } \\
\text { Error }\end{array}$ & $p$-Value \\
\hline CW (water) & $0.05141^{* * *}$ & 0.00470 & 0.000 & $0.07270 * * *$ & 0.00703 & 0.0000 \\
\hline CWI (wildlife) & $0.05135^{* * *}$ & 0.00437 & 0.000 & $0.03813^{* * *}$ & 0.00815 & 0.0000 \\
\hline CL (landscape) & $0.03349^{* * *}$ & 0.00432 & 0.000 & $0.03180 * * *$ & 0.00630 & 0.0000 \\
\hline $\mathrm{CP}$ (price) & $-0.03709^{* * *}$ & 0.00296 & 0.000 & $-0.03739 * * *$ & 0.00298 & 0.0000 \\
\hline CWAR (water_res-) & & & & $-0.02464^{* * *}$ & 0.00804 & 0.0022 \\
\hline CLR (landsc_res) & & & & $0.01833^{* *}$ & 0.00777 & 0.0183 \\
\hline CLG (landsc_gen) & & & & $-0.01754^{* *}$ & 0.00769 & 0.0224 \\
\hline CWII (wild_inc) & & & & $0.00439 *$ & 0.00228 & 0.0544 \\
\hline CWAB (wat_env) & & & & $-0.01963^{* *}$ & 0.00766 & 0.0103 \\
\hline \multicolumn{7}{|c|}{ Summary statistics } \\
\hline Log-likelihood & & -1510.27924 & & & -1496.00282 & \\
\hline $\mathrm{AIC} / \mathrm{N}$ & & 2.012 & & & 2.000 & \\
\hline Pseudo- $R^{2}$ & & 0.0641 & & & 0.0729 & \\
\hline Observations & & 1505 & & & 1505 & \\
\hline
\end{tabular}

* Significant at $10 \%$ level. ** Significant at $5 \%$ level. ${ }^{* * *}$ Significant at $1 \%$ level.

The signs of the coefficients for all attributes in both models are as expected and statistically significant at $1 \%$ level. Water, wildlife, and landscape coefficients are positive, meaning improvement of these attributes leads to the gained utility of the respondents. Negative price coefficients suggest that the respondents were willing to accept the policy with lower cost to them.

The MNL results show that the socioeconomic characteristics and knowledge on the impact of agricultural activity variables influence the respondents' choices and preferences: (i) negative and significant coefficient of water quality and residence interaction suggests that the residents from rural areas would be less inclined to choose improvements in the water quality because of the agricultural activity compared to the residents from urban areas. The relationship between the agricultural landscape and place of residence has shown the opposite situation, when people from rural areas are more likely to choose the agri-ecosystem compared to those from urban areas; (ii) negative and significant coefficient of the water quality and gender relationship indicates higher willingness to pay for drinking water quality by women compared to men (men would choose improvements in the water quality more rarely); (iii) positive and significant sign of the relationship between wildlife and resident income suggests that the respondents gaining more income would 
choose the program for improvement of wildlife populations more frequently. Based on the MNL model II, the implicit prices/WTP for the attributes analyzed were calculated, as described in Equation (3). According to the results, the respondents' MWTP/person for water quality was EUR 1.94 for the reduction in underground water pollution due to agricultural activity by 1\%; EUR 1.02 for improvement for protecting the diversity of wildlife; and EUR 0.85 for an improved agricultural landscape. The trade-off between attributes indicated that Warmia and Mazury region residents gave preference to water quality, while wildlife populations and agricultural landscape attained lower preferences.

Results for the WTP estimates for the different levels of provision considering the attributes (10\% and $20 \%$ improvements) are presented in Table 7.

Table 7. Implicit prices for attributes in choice sets (EUR/hh/year).

\begin{tabular}{ccc}
\hline Attributes & MWTP 10\% & MWTP 20\% \\
\hline Water quality & 19.4 & 38.8 \\
\hline Wildlife populations & 10.2 & 20.4 \\
\hline Agricultural landscape & 8.5 & 17.0 \\
\hline
\end{tabular}

Consumers' willingness to pay substantiates their higher concerns about the drinking water quality. It shows that residents of Warmia and Mazury were mostly concerned about the primary needs. The analysis of their opinions has shown that biodiversity and landscape services were less significant for them, which was substantiated with the lowest willingness to pay for these services.

\section{Discussion}

Findings of the current research about consumer preferences for AES are in line with the previous studies. Research has shown that the water quality is the most important attribute for consumers $[11,30,34,35]$, which is in line with our findings. The respondents ranked biodiversity second by importance, as found previously by Faccioni et al. [11]. As highlighted by Soini and Aakkula [36], the main reason is that people could see and feel the direct effect of water quality on their welfare. They are not able to estimate the consequences of loss in biodiversity, because the overall concept and importance of biodiversity for people is not usually understood [6]. Being unconscious of the concept biodiversity is due to its intangibility $[2,6,36]$. Our research has revealed that the agricultural landscape the least important for the respondents, thus substantiating the conclusions of the previous research $[11,26,30]$.

Bernués et al. [6], Alcon et al. [37] and Rodríguez-Ortega et al. [38] obtained biodiversity and landscape values higher than the results obtained by current research. This happened due to the lower of income level of Warmia and Mazury region residents. Similar results of willingness to pay were obtained by Novikova [24], who assessed willingness to pay for AES in Lithuania, where the level of subsistence was more similar to Poland.

Our results underline the importance of AES depending on respondents' socioeconomic characteristics and individuals' backgrounds and interests, the same as in the research by Faccioni et al. [11]. For example, women have a higher willingness to pay for AES than men do. These findings are in line with other research [38]. Similarly to other studies [34], the present research has revealed that higher income respondents have higher willingness to pay for agroecosystem services. Arriaza et al. [9] and Baskaran et al. [34] have found out that respondents from urban and rural areas have different opinions about agroecosystem services; urban residents show a higher willingness to pay than those from rural areas. The present research has found that urban residents were willing to pay less for drinking water quality than rural residents. Respondents who had more knowledge about the impact of agriculture on nature were willing to pay less for AES (drinking water quality in current study), as shown by other studies $[13,24,28,30]$. 


\section{Conclusions}

The present study was the first instance of CE application in the Warmia and Mazury region. The focus was to analyze the local residents' preferences towards the provision of AES. According to the characteristics of the Warmia and Mazury province, it is an agricultural region with high natural values. The obtained research results may have practical application in shaping agricultural policy at the regional level, in creating smart specializations by including them in strategic documents concerning the region.

The study has clearly shown that residents of Warmia and Mazury region were concerned about environmental problems caused by agriculture. The results of the study have revealed that, in environmentally rich areas such as Warmia and Mazury region, agriculture is multifunctional, delivering multiple AES highly important for the society. Particularly strong support was claimed towards the provision of AES, such as water quality and wildlife populations.

Three AES (water quality, wildlife populations, and agricultural landscape) were selected for evaluation for the Warmia and Mazury region. The choice was made according the analysis of the situation in the region and extensive literature research about the impacts of agricultural activity. In exploration of the choice experiment method, the value was calculated and expressed as average personal contribution (EUR per year for the next five years), expressed in implicit prices. The study has revealed that the socioeconomic characteristics and knowledge about agricultural activity impact influence consumers choices and the WTP for AES. Women, higher income residents and residents from rural areas are more willing to pay for AES, in particular, for drinking water quality. The present study results are in line with similar research performed by other scientists. However, the values of WTP were lower compared to other studies. These results may have been influenced by lower income level of Warmia and Mazury region residents.

It should be noted that the present study has limitations, because it covered only three attributes (water, biodiversity and landscape). Current agri-environmental policy measures cover a lot more ES. Therefore, an even more detailed study could be carried out in the future, the results of which would be applied for the development of agrienvironmental policy measures, or as suggested by Niedermayr et al. (2018) [39], could aim to evaluate the willingness of farmers to accept for the implementation of environmentally friendly farming practice

Author Contributions: The authors equally contributed to the current research paper. S.B. and B.V. wrote the Introduction section; R.M.-B. together with A.N. wrote the Materials and Methods and Results. All the authors shared and wrote the Discussion and Conclusions. All authors have read and agreed to the published version of the manuscript.

Funding: This research received no external funding.

Informed Consent Statement: Informed consent was obtained from all subjects involved in the study.

Conflicts of Interest: The authors declare no conflict of interest.

\section{References}

1. Choruma, D.J.; Odume, O.N. Exploring Farmers' Management Practices and Values of Ecosystem Services in an Agroecosystem Context-A Case Study from the Eastern Cape, South Africa. Sustainability 2019, 11, 6567. [CrossRef]

2. Petway, J.R.; Lin, Y.P.; Wunderlich, R.F. A Place-Based Approach to Agricultural Nonmaterial Intangible Cultural Ecosystem Service Values. Sustainability 2020, 12, 699. [CrossRef]

3. Christiansen, S. On classification of agricultural systems-An ecological approach. Geogr. Tidsskr. 1979, 79, 1-4. [CrossRef]

4. Swinton, S.M.; Lupi, F.; Robertson, G.P.; Hamilton, S.K. Ecosystem services and agriculture: Cultivating agricultural ecosystems for diverse benefits. Ecol. Econ. 2007, 64, 245-252. [CrossRef]

5. Garbach, K.; Milder, J.C.; Montenegro, M.; Karp, D.S.; De Clerck, F.A.J. Biodiversity and Ecosystem Services in Agroecosystems. Encycl. Agric. Food Syst. 2014, 2, 21-40. [CrossRef]

6. Bernués, A.; Alfnes, F.; Clemetsen, M.; Eik, L.O.; Faccioni, G.; Ramanzin, M.; Ripoll-Bosch, R.; Rodríguez-Ortega, T.; Sturaro, E. Exploring social preferences for ecosystem services of multifunctional agriculture across policy scenarios. Ecosyst. Serv. 2019, 39. [CrossRef] 
7. Bennett, J.; Blamey, R. The Choice Modelling Approach to Environmental Valuation, New Horizons in Environmental Economics; Edward Elgar: Cheltenham, UK; Northampton, MA, USA, 2001.

8. Hanley, N.; Mourato, S.; Wright, R.E. Choice modelling approaches: A superior alternative for environmental valuation? J. Econ. Surv. 2001, 15, 435-462. [CrossRef]

9. Arriaza, M.; Gomez-Limon, J.A.; Kallas, Z.; Nekhay, O. Demand for non-commodity outputs from mountain olive groves? Agric. Econ. Rev. 2008, 9, 5-23.

10. Domínguez-Torreiro, M.; Soliño, M. Provided and perceived status quo in choice experiments: Implications for valuing the outputs of multifunctional rural areas. Ecol. Econ. 2011, 7, 2523-2531. [CrossRef]

11. Faccioni, G.; Sturaro, E.; Ramanzin, M.; Bernués, A. Socio-economic valuation of abandonment and intensification of Alpine agroecosystems and associated ecosystem services. Land Use Policy 2019, 81, 453-462. [CrossRef]

12. Lankia, T. The Economic Value of the Priceless: Revealing the Benefits of Outdoor Recreation in Finland. Ph.D. Thesis, Natural Resources Institute Finland, Helsinki, Finland, 13 March 2020.

13. Grammatikopoulou, I.; Pouta, E.; Salmiovirta, M.; Soini, K. Heterogeneous preferences for agricultural landscape improvements in Southern Finland. Landsc. Urban Plann. 2012, 107, 181-191. [CrossRef]

14. Włodarczyk-Marciniak, R.; Piotr Frankiewicz, P.; Krauze, K. Socio-cultural valuation of Polish agricultural landscape components by farmers and its consequences. J. Rural Stud. 2020, 74, 190-200. [CrossRef]

15. Czyżewski, B.; Matuszczak, A.; Czyżewski, A.; Brelik, A. Public goods in rural areas as endogenous drivers of income: Developing a framework for country landscape valuation. Land Use Policy. in press.

16. Characteristics of Warmia and Mazury Province. Available online: https://bip.warmia.mazury.pl/informacja/1/ogolnacharakterystyka-wojewodztwa-warminsko-mazurskiego.html (accessed on 5 July 2019). (In Polish).

17. Jasiński, J.; Kostyk-Wodzińska, E.; Suchta, J. Środowisko przyrodnicze filarem województwa warmińsko-mazurskiego w warunkach integracji z Unia Europejska. (The natural environment is a pillar of the Warmia and Masuria Province in the conditions of integration with the European Union. Acta Sci. Pol. Adm. Locorum 2004, 3, 5-16. (In Polish)

18. Encyclopedia. Available online: http://encyklopedia.warmia.mazury.pl/index.php/Wojew\%C3\%B3dztwo_warmi\%C5\%84skomazurskie (accessed on 5 July 2019). (In Polish).

19. Lancaster, K.J. A new approach to consumer theory. J. Polit. Econ. 1966, 74, 132-157. [CrossRef]

20. Thurstone, 1. A law of comparative judgement. Psychol. Rev. 1927, 34, 273-286. [CrossRef]

21. Jianjun, J.; Chong, J.; Thuy, T.D.; Lun, L. Public preferences for cultivated land protection in Wenling city, China: A choice experiment study. Land Use Policy 2013, 30, 337-343. [CrossRef]

22. Bateman, I.J.; Carson, R.T.; Day, B.; Hanemann, M.; Hanley, N.; Hett, T.; Jones-Lee, M.; Loomes, G.; Mourato, S.; Özdemiroglu, E.; et al. Economic Valuation with Stated Preference Techniques: A Manual; Edward Elgar: Cheltenham, UK, 2002.

23. Mazzanti, M.; Montini, A. "Valutazione Economica Multi-AttributoMediante Esperimenti di Scelta Aspetti Metodologici e Strumenti di Analisi Econometrica." (Multiattribute Economic Evaluation by Means of Choice Experiments. Methodological Aspects and Econometrics Analysis Tools). In Proceedings of the XIII conference SIEP: "Stato o mercato? Intervento pubblico e architettura dei mercati" (State or Market? Public Interventions and Markets Structure), University of Pavia, Pavia, Italy, 5-6 October 2001.

24. Novikova, A. Agroaplinkos Išorinių Padarinių Vertès Integravimas ị Žemès Ūkio Produktyvumo Vertinima (Integration of Value of Agri-environmental Externalities into Measurement of Agricultural Productivity). Ph.D. Thesis, Aleksandras Stulginskis University, Akademija, Lithuania, 16 December 2016. (In Lithuanian).

25. Gwiaździńska-Goraj, M.; Goraj, S. The Contribution of the Natural Environment to Sustainable Development on the Example of Rural Areas in the Region of Warmia and Mazury. J. Rural Dev. 2013, 6, 266-271.

26. Baskaran, R.; Cullen, R.; Colombo, S. Estimating values of environmental impacts of dairy farming in New Zealand. N. Z. J. Agric. Res. 2009, 52, 377-389. [CrossRef]

27. Goibov, M.; Schmitz, P.M.; Bauer, S.; Ahmed, M.N. Application of a choice experiment to estimate farmers preferences for different land use options in Northern Tajikistan. J. Sustain. Dev. 2012, 5, 2-16. [CrossRef]

28. Takatsuka, Y.; Cullen, R.; Wilson, M.; Wratten, S. Values of Ecosystem Services on Arable Land and the Role of Organic Farming. In Proceedings of the 2005 NZARES Conference Tahuna Conference Centre, Nelson, New Zealand, 26-27 August 2005.

29. Hasund, K.P.; Kataria, M.; Lagerkvist, C.J. Valuing public goods of the agricultural landscape: A choice experiment using reference points to capture observable heterogeneity. J. Environ. Plan. Manag. 2011, 54, 31-53. [CrossRef]

30. Colombo, S.; Hanley, N.; Calatrava-Requena, J. Designing policy for reducing the off-farm effects of soil erosion using choice experiments. J. Agric. Econ. 2005, 56, 81-95. [CrossRef]

31. McFadden, D. Conditional logit analysis of qualitative choice behaviour. In Frontiers in Econometrics; Zarembka, P., Ed.; Academic Press: New York, NY, USA, 1974.

32. Ben-Akiva, M.; Lerman, S. Discrete Choice Analysis. Theory and Application to Travel Demand; MIT Press: Cambridge, MA, USA, 1985.

33. Mazzocchi, C.; Sali, G. Assessing the value of pastoral farming in the Alps using choice experiments: Evidence for public policies and management. J. Environ. Plan. Manag. 2019, 62, 552-567. [CrossRef]

34. Baskaran, R.; Cullen, R.; Takatsuka, Y. Estimating the value of agricultural eco-system services: A case study of New Zealand pastoral farming. Australas. J. Environ. Manag. 2009, 16, 103-112. [CrossRef] 
35. Borresch, R.; Maas, S.; Schmitz, K.P.; Schmitz, M. Modelling the value of a multifunctional landscape-A discrete choice experiment. In Proceedings of the International Association of Agricultural Economists Conference, Beijing, China, 16-22 August 2009.

36. Soini, K.; Aakkula, J. Framing the biodiversity of agricultural landscape: The essence of local conceptions and constructions. Land Use Policy 2007, 24, 311-321. [CrossRef]

37. Alcon, F.; Marín-Miñano, C.; Zabala, J.A.; De-Miguela, M.D.; Martínez-Paz, J.M. Valuing diversification benefits through intercropping in Mediterranean agroecosystems: A choice experiment approach. Ecol. Econ. 2020, 171, 106593. [CrossRef]

38. Rodríguez-Ortega, T.; Bernués, A.; Alfnes, F. Psychographic profile affects willing-ness to pay for ecosystem services provided by Mediterranean high nature value farmland. Ecol. Econ. 2016, 128, 232-245.

39. Niedermayr, A.; Schaller, L.; Mariel, P.; Kieninger, P.; Kantelhardt, J. Heterogeneous Preferences for Public Goods Provided by Agriculture in a Region of Intensive Agricultural Production: The Case of the Marchfeld. Sustainability 2018, 10, 2061. [CrossRef] 